\title{
A confessing church at war with itself: The significance of the relationship between the concepts "Gospel and law"
}

\author{
Tshaka, Rothney $S$ \\ University of South Africa \\ tshakrs@unisa.ac.za
}

\begin{abstract}
The confessing movement of Germany has influenced the South African confessional movement. Although the confessing movement of Germany was successful in alerting some Christians of the ills of nationalism and the concoction of nationalism with theology, this movement was not without its own challenges. One major challenge was revealed in terms of how the concepts Gospel and Law were related with one another. Being constituted by different ecclesial traditions, it lacked a clear consensus of how to deal with secular law, which was considered to be of concern by the state. A separation between gospel and law, which is sometimes insisted upon especially in some theological traditions is seen in this article as one contributing factor to the German church's late reaction to the Jewish question.
\end{abstract}

Keywords

Gospel and law, confessional church, Karl Barth, Barmen Declaration, Jewish question, Belhar Confession.

\section{Introduction}

The confessing church in Germany which was essentially called into existence by the theological quandary that the church found itself in under the Hitler regime has played a significant role in dealing with the church's responsibility in the world today. This act however was not without its own challenges about how the church should deal with this responsibility. These challenges were precipitated by the many theological interpretations that were united with the aim of ensuring the independence of the church under the regime in question. One significant theological interpretation centered 
on the concepts "Gospel and Law". It was also the different interpretations of these concepts, which resulted in the different views of how the church can and must be involve in the affairs of society.

This article will attempt to probe the interpretation of the concepts in question by some of the major theological traditions that were aligned with the confessing church. By doing this, it hopes to illustrate the reason(s) why Karl Barth became increasingly unpopular within the confessing movement. It will also be displayed that an interpretation that sought the relationship between Gospel and Law as intrinsic, facilitated the church's response to the Jewish question. In the end a few comments are made about the Barmen Theological Declaration, which in essence sees no dichotomy between Gospel and Law.

\section{Squabbles within a confessing church}

Numerous students of the theology of Karl Barth have suggested that there are significant grounds to surmise that the politico-economic situation in which his theology was practiced is fundamental to a better comprehension of his theology (Marquardt 1976:47-77; see also Gorringer 1999). Some of those who were uncomfortable with such a reading of Barth have ventured to dismiss such claims and had therefore deliberately ignored Barth's frequent caution to the significance of having the newspaper in sight while attending to the matters of Scripture. This ethical component which is always implied in Barth's theology is also evident in the Barmen declaration ${ }^{1}$ which can also be construed as a summary of his theology, as

1 The word declaration is used because of the view that Lutheranism has with regard to the understanding of a confession. Since this article is written by a reformed Christian, the word confession will sometimes be used because this is a notion that is understood differently within the said theological tradition. It is indeed interesting to use the notion of confession more in relation to the Barmen declaration because it was this declaration, which more than other local declaration, influenced the Belhar Confession. One can think of many declaration made during apartheid, i.e. message of the people etc, but it was the? Barmen declaration that galvanized the reformed confessional tradition into penning its own confession, called the Belhar Confession. The usage of the notion confessional in relation to the Barmen declaration is therefore deliberate in this article. The Full title of the declaration reads: "Declaration concerning the right understanding of the Reformation confessions of faith in the German Evangelical Church of the present". This declaration was the result of the confessional synod of the German Evangelical Church, which convened in Barmen on 29-31 May 
well as the Belhar Confession which partly came into being through the inspiration of the theology of Barth.

The question of which one of these two items (the Bible and the newspaper) takes precedence is displayed in Barth's stern emphasis on the Word of God as the point of departure in theological reflections. However although the Word is preferred above other items, it would be unfair to insinuate that the secondary item (in this case the newspaper) did not influence the outcome of a particular theological reflection with which he concerned him. It is particularly important that we deal with the political situation, which necessitated Barth's theological position on the question of the Jews (Judefrage) and the consequent tension, which ensued between him and the Confessing Church.

The position of Barth as chief author of the Barmen theological declaration as well as a vocal member of the confessing church was for a long time seen as being controversial. With reference to Barth it must swiftly be stated that he was blamed for not having said and done enough to alleviate the plight of the Jews under the Hitler regime. Busch refers to a critique by Scholder leveled against Barth. Scholder interpreted the political situation in Germany in the following way. He believes that in 1933, Barth with his strong emphasis on the first commandment and the exclusive and binding force of God's Word made a decision that, though somehow well intentioned should have been expressed intolerantly. Scholder charged that the weakness of this was that in focusing upon the preservation of pure doctrine in the pulpits of the church it saw no challenge in the Nazi state itself. Thus it had the disadvantage of inevitably glossing-over the significance of the so-called Jewish question. Barth is then blamed for the struggling confessing church's hindsight of the crisis of the Jews, simply because he was a chief contributor to a decision which called into disrepute the justification of the Jewish discrimination (Busch 2004:54).

1934. The meeting was constituted by members of the Lutheran, Reformed and United churches, seeking a common message against the attempts of Hitler and the Nazis to co-opt the church and make it subservient to Nazi ideology and its Aryan policies (Cf. RS Tshaka, Confessional Theology? A Critical Analysis of the Theology of Karl Barth and its Significance for the Belhar Confession. Newcastle: Cambridge Scholars Publishing. 2010:83). 
Busch question the sincerity of those who hesitate to agree that Barth was on the contrary not unaware of that, which afflicted the Jews. While admitting that Barth personally thought that he had not done enough in this respect, Busch asserts that allegations which implied that Barth remained lethargic towards the Jews is frivolous since, he argues, "it was Barth and not Gogarten, Hirsch or Althaus who finally articulated a confession of repentance towards the Jews, a very confession which is also interpreted as his admission of the failure of the confessing church in dealing more proactively with the Jewish question" (Busch 2004:54). It is Busch's view that during the time of Barth's direct involvement in the German church struggle, he fought for the principle of the exclusive binding character of God's Word. He however cautions that the motive behind this be to comprehended. Initially it ought to be understood that what was central to him was not his criticism of the "German Christians" ${ }^{2}$ - who admittedly were unacceptable to him. Instead it was his criticism of the inner church opposition against the "German Christians".

It must then be stated that as much as the Barmen theological declaration was opposed to the "German Christians", it was just as much opposed to the confessing church which was the revised version of the Pastor's Emergency League. It was to this group that theologians such as Karl Heim, Hanns Lilje, Martin Niemöller and Dietrich Bonhoeffer belonged (Busch 2002:67). The Barmen confession opposed this group for it called for the complete freedom of the church "from all political influence" and in this sense criticized the "German Christians". It is perhaps not emphasized enough that this confession was a confession not of a triumphant church, but of a repentant church. The lack of insisting on this attitude drove Barth to maintain in 1933 that the confessing church was saying secretly the same thing that the German Christians were saying openly (Busch 2002:67).

2 With the rise of National Socialism a further division occurred among the Protestants. The one group was the Confessing Church led by the reverend Martin Niemöller, while the other group was the "German Christians" faith movement - the more fanatical Nazis led by Ludwig Mueller. He was an army chaplain of the East Prussian Military district and a devoted follower of Hitler. This movement ardently supported the Nazi doctrines of race and the leadership principle and wanted them applied to the Reich Church which would bring all Protestants into one all-embracing body (cf. W Shirer 1961:235); the "leader principle" presupposed that the church was to be organised according to the same principle as the state: "one empire, one leader" (cf. M LehmannHabeck 1998. Confession and Resistance in Hitler-Germany (1933-1945). In: Mission Studies. 2(1):34-38. 
Busch maintains that while on the one hand this group called for the complete freedom of the church "from all political influence"; and in this sense it criticized the "German Christians", they on the other hand articulated a "joyful Yes to the new state", and wanted to bind the church to an "indissoluble service to the German volk" (Busch 2002:67). By doing this, this group was advocating an analysis, which insinuated that the church and the state were two entities which co-exist and therefore mutually recognizes each other without intervening in the other's affairs.

Busch charges this group for having misunderstood what "confessing" really meant. He is of the view that this group understood about this subject not God's mercy and righteousness over against the destructive powers, but instead they thought by confession the most fundamental thing is to protect the church and its confessional stance over against interventions into its life from outside (Busch 2002:67). It was this view, which allowed this group to declare the unshakable loyalty of the church to the authoritarian nationalistic state. This was the very issue, which forced Barth to register his disdain with the conduct displayed by this group. In opposing this conduct Barth wrote in 1933: "the assumption that one could be in agreement with the preamble of the "German Christians" (in their affirmation of the Nazi state), and then later, have a pure church in opposition to them "...will prove to be one of the most deceptive illusions of an era replete with such illusions. Let us leave out the preamble, completely and sincerely, and then we will speak further about that which follows" (Busch 2004:56).

\section{The impact that the two-sector doctrine has on theological reflection}

There is a stark difference between the theology of the so-called "German Christians" and the theology of the confessing church. It is perhaps important to be briefly reminded that the confessing church was a combination of various theological traditions. In the case of the confessing church we see a combination of Reformed, Lutheran and United theological traditions, which do not differ greatly although there are some significant differences. While it was clear that in the case of the former a concoction of Christendom and Nazi ideology dictated the form of the German Christians, in the latter group one is confronted with a type of 
two-sector doctrine, which was predominant in this church's opposition to the German Christians.

One way of interpreting the two-sector doctrine during the Hitler regime can briefly be explained as Busch did: "...politically one could be a brownshirt or German nationalist, and therefore ipso facto be supportive of the state's treatment of the Jews as long as it proceeded 'lawfully'. Ecclesiastically, one wanted to preserve the confessional stance as inviolable, and therefore not separate oneself from the baptized Jews, even though one viewed them as a foreign race" (Busch 2004:56). Barth thought that it was entirely pointless to leave the church on account of the latter, as Bonhoeffer once recommended, in order to build a free church on the foundation of such a two-sector doctrine (Busch 2004:56). For Barth it was more important to repudiate that existing misunderstanding of the church and her relation to the world.

It is this frivolous interpretation of the two kingdom doctrine which forced Barth to respond to Bonhoeffer. Bonhoeffer had maintained that: "the true church of Christ... will never meddle in the state's affairs...The church knows that in the world the use of violent force inevitably is joined with the moral injustice of certain actions of the Government.' Therefore, in the question of the Jews the church today is not allowed to interrupt the government immediately and to demand another policy" (Bonhoeffer in Busch 2002:68).

Barth according to Busch was particularly critical of the confessing church because he believed that it erred in its idea that for Christians in their life outside the church the Word of God, as attested in Scripture, is suspended. It was this suspension, which then enabled a surrendering of their daily lives to the secular powers, something which was not different from the German Christians (Busch 2002:69). The removal of the German Christians from the church was therefore according to Barth no gain because their errors then remained in the church and therefore the church was then wrong in itself. Barth believed that the church could therefore only become a confessing church when it rid itself from that idea (Busch 2002:69).

It was therefore important, at least for Barth, to spend some time discussing the problematic of this two-sector doctrine which for him is located at the heart of his engagement with gospel and law (the inseparability of 
dogmatics and ethics). Barth's Christian ethics takes its point of departure in the formula "Gospel and Law" which for him was also the basic substance of his dogmatics (Busch 2004b:152). Simply stated, the gospel speaks about God's will for us while the law tells us what God wills from us. Although they are two issues, because in both we encounter the same God who has a relationship with humanity. They are therefore not to be separated although they are two distinctive issues.

Karl Barth deals extensively with the subject "Gospel and Law" in his CD II/2 especially in the chapters 36-39. In the chapters mentioned, Barth makes it clear that ethics interprets the law as the form of the gospel (Barth CD II/2: 509). Barth's usage of ethics in line with gospel and law also demonstrates his disdain for the separation of ethics from dogmatics. Having pointed this out, it then goes without saying that ethics remains essential in our deliberations concerning gospel and its relationship to law.

As much as the chapters in question remains fundamental to our understanding of how the gospel relates to the law, it is his later work which re-invites us to ponder the significant relationship which exist between gospel and law. In CD IV.3.1 it becomes almost immediately clear that the compulsion that he felt for dealing with these subjects stemmed from the criticism, which he received from theologians of the Lutheran traditions especially by Lutheran theologians such as W Elert, P Althaus, E Sommerlath, H Thielicke, et al (Barth CD IV/3.1: 370).

These Lutheran theologians believed that Barth did not comprehend the relationship between these concepts and that his interpretation, which insists that they ought to be seen as unified is not convincing. The issues raised by these theologians leaves Barth with the need of deciphering the possibility of whether he had completely misread Luther or whether he simply did not know Luther at all, both of which are postulates that he does not seem to want to entertain. Barth is certainly aware that Luther himself has been a rather controversial person when it comes to these issues. $\mathrm{He}$ believes that with the following issues in which he outlines his confusion with regard to the interpretation of Gospel and Law, one sees more than one Luther (Barth CD IV/3.1: 371). It is for this reason that he felt compelled to raise the following problems concerning an interpretation, which insist on the separateness of Gospel from Law. 
Barth argues that the theologians in question do not possess sufficient biblical grounds to dispute his interpretation of these subjects. He therefore tables the following points, which register his confusion about the counterthesis raised by them. He writes: "I do not understand with what biblical or inherent right, on the basis of what conception of God, His work and His revelation, and above all in the light of what Christology, they can speak, not of one intrinsically true and clear Word of God, but of two Words in which He speaks alternately and in different ways to man according to some unknown rule" (Barth CD IV/3.1: 370).

He believes that the type of gospel that they advocate is problematic since it does not deal with the matters of forgiveness adequately. In light of this view, he raises the following misunderstanding that he has with regard to their critique of his interpretation. He writes: "I do not understand the meaning of a supposed Gospel the content of which is exhausted by the proclamation of the forgiveness of sins and which is to be received by man in a purely inward and receptive faith; nor of a supposed Law which as an abstract demand can only be an external ordinance on the one side but on the other is ordained to accuse man and therefore to indicate and prepare the way for the Gospel" (Barth CD IV/3.1: 370).

Barth continues to raise another misunderstanding, claiming that he finds it, "difficult to comprehend how a concept of a supposed Law can be attained or exploited except (as in the $16^{\text {th }}$ century, and with very serious consequences in the $17^{\text {th }}, 18$ th and $19^{\text {th }}$ ) by appealing to the idea of a natural law and therefore of a general natural revelation, or by falling back on a most primitive form of Biblicism; and I am surprised that this dilemma has not been accepted as a warning" (Barth CD IV/3.1: 370).

Karl Barth believed that it was the divorce between these issues, which in 1933 and 1934 enabled the Protestant theologians to affirm the authoritarian and radically nationalist Führer-state. Because Barth believed that gospel and law belonged together, he believed that to equate obedience to the Führer with obedience to God was the fruit of an older theological error (Busch 2004b:156). The error which has been created in the interpretation of the gospel independent of the law which had allowed the likes of Friedrich Gogarten to declare that the law of God 'encounters the modern generation concretely in the form of the national socialist movement in both state 
and people," as a "hard" but for this reason an "authentic law" (Busch 2004b:156). Busch rightly maintains that this would exclude a "specifically Christian' or "biblical" law". Instead the church must be the "nurse and guardian" of the law that is given in nationhood. It must also preach the gospel of forgiveness, though this does not relate to offenses against that external "law" (Busch 2004b:156).

\section{The Barmen theological declaration and the future: A conclusion}

From the commentaries that have been written about this confession it had become clear that this confession was never meant to stand the test of time. ${ }^{3}$ By suggesting that the authors as well as the synod that adopted this confession did not think about the necessity of this confession to stand the test of time, does not suggest that this confession would become irrelevant in another time and context, instead to deny this confession some kind of timelessness is simply stimulated by the appreciation of the temporal context of this confession.

Remembering that this was a confession, which was borrowed by reformed churches in particular around the world implies that many thought and still think that the context which precipitated this confession also applied to other contexts. The authorship of confessions such as the Belhar Confession of South Africa has confirmed this belief. Despite the fact that the Belhar Confession was influenced by the theology that influenced the Barmen Declaration, it has become clear that the socio-economic, political and cultural contexts were different to those contexts that necessitated Barmen. Put this way, the Belhar Confession is not a copy of the Barmen Declaration, but it engaged in a critically theological and political conversation with the Barmen confession. South African theologians such as Smit prefer to speak about a conversation between the Barmen declaration and the Belhar confession, which has been going on for quite some time now (Smit 2006: 291-302).

3 Among the many commentaries we find the one by E Busch to be particularly innovative in pointing this view out. (See Busch 2002:64-82). 
What cannot be denied of the Barmen Declaration is that it had inevitably made an indelible impression on the Reformed history of the $21^{\text {st }}$ century, yet for this confession to retain its vitality it has become imperative that those who draw from its wells understand that occasions will continue to arise in which the church will have to confess its faith in the light of a palpable thread. Furthermore it would have been very arrogant for both this confession as well as its adherents to insist on its timelessness. It is most helpful to emphasis the humility in confessing which this confession hoped to illustrate but has never been stress more emphatically. In addition to this, it is also imperative that those who ascribe to this confession learn from the mistakes that were committed both by the interpreters of the Barmen confession and as well as the mistakes inherent in it. We have tried to point out some of the criticisms leveled against this confession by among others the chief author of this confession. It would therefore be a great injustice done to this confession when the shortcomings to these confessions are also not referred to when treating the essence of this confession in the current context.

Although the Barmen confession can be considered an event that was necessitated by particular socio-political and theological facets, it nonetheless remains also a process. It remains a process because it reveals the church as being perpetually involved in an attempt of defining its faith to those outside of it. It is also a process for it has to probe continuously the church's faithfulness and obedience to its head Jesus Christ. More than 25 years after the draft Belhar Confession, it would seem that it has become time for us to engage both the strengths and weaknesses of the Belhar Confession. It was clear that Barth and others had to be more vocal after Barmen because they had thought that the socio-economic issues related to the Jewish question was not highlighted well enough. Perhaps it has now become the most opportune time for those who subscribe to the Belhar confession to begin to interrogate the accompanying letter ${ }^{4}$ which had as

4 In his book, Confessional theology, RS Tshaka explains the accompanying letter as an apology to the then apartheid regime. He maintain that the accompanying letter is produced to assure the then regime that the church which produced the Belhar Confession, does not intend to become an alternative to the then apartheid regime but recognises the position of those who are on the margins of society to confess when the gospel is at stake. (Tshaka 2010:257). That view has since changed and the author looks at that statement in a more critical manner in (the?) light of his new found insights of the debates post Barmen. 
its intention to objective of not pointing clearly to the apartheid question and to call to order those who associated with such an ideology. By taking a leaf from the discourse on the Jewish question and the Barmen declaration, we in South Africa will perhaps be moving a step closer to dealing with the race question which seems to have been avoided at all cost in reformed theological discourse today.

\section{Bibliography}

Busch, E 2002. The Barmen Declaration: Its theology, background and reception. In: Van der Borght, AJG; Van Keulen, D and Brinkman, ME (eds.). Studies in Reformed theology: Faith and Ethnicity. Vol. 2. Meinema: Zoetermeer.

Busch, E 2004. Indissoluble Unity: Barth's Position on the Jews during the Hitler Era. In: Hunsinger, G (ed.). For the Sake of the World: Karl Barth and the Future of Ecclesial Theology. Grand Rapids: Eerdmans.

Busch, E 2004b. The Great Passion: An introduction to Karl Barth's theology. Grand Rapids: Eerdmans.

Marquardt, F. 1976. Socialism in the theology of Karl Barth. In: Hunsinger, G (ed.). Karl Barth and radical politics. Philadelphia: Westminster Press.

Gorringer, T 1999. Karl Barth against hegemony. Oxford: Oxford University Press.

Smit, DJ 2006. Barmen and Belhar in Conversation - A South African Perspective. In: NGTT. 47(1\&2):291-302.

Tshaka, RS 2010. Confessional Theology? A Critical Analysis of the Theology of Karl Barth and its Significance for the Belhar Confession. Newcastle: Cambridge Scholars. 